\title{
Polymerization of Ethylene Glycol Dimethacrylate (EGDM), Using An Algerian Clay as Eco-catalyst (Maghnite- $\mathrm{H}^{+}$and Maghnite-Na ${ }^{+}$)
}

\author{
Sara Haoue ${ }^{1}$, Hodhaifa Derdar ${ }^{1,2, *}$, Mohammed Belbachir ${ }^{1}$, Amine Harrane ${ }^{1,3}$
}

${ }^{1}$ Laboratoire de Chimie des Polymères, Département de Chimie, FSEA, Université Oran1 Ahmed Ben Bella, BP $N^{\circ} 1524$ El M'Naouar, 31000 Oran, Algeria.

${ }^{2}$ Centre de Recherche Scientifique et Technique en Analyses Physico-Chimiques (CRAPC), BP 10384 , Siège ex-Pasna Zone Industrielle, Bou-Ismail CP 42004, Tipaza, Algeria.

${ }^{3}$ Dept. of Chemistry, FSEI, University Abdelhamid Ibn Badis Mostaganem, Algeria.

Received: $10^{\text {th }}$ November 2019; Revised: 14th January 2020; Accepted: $15^{\text {th }}$ January 2020; Available online: 28th February 2020; Published regularly: April 2020

\begin{abstract}
In this paper we have explored a novel and green method to synthesis and polymerize ethylene glycol dimethacrylate (EGDM). This technique consists on using Maghnite (Algerian clay) as a green catalyst to replace toxic catalysts. The Algerian clay has been modified using two ion exchange process to obtain Maghnite- $\mathrm{H}^{+}$(proton exchanged process) and Maghnite- $\mathrm{Na}^{+}$(sodium exchanged process). Synthesis experiments of EGDM and Poly (EGDM) are performed in bulk respecting the principles of green chemistry. The structure of the obtained monomer and the obtained polymer was confirmed by FT-IR, ${ }^{1} \mathrm{H}$ NMR and ${ }^{13} \mathrm{C}-\mathrm{NMR}$, where the methacrylate end groups are clearly visible. The presence of unsaturated end group in the structure of monomer was confirmed by UV-Visible analysis. Thermogravimetric Analysis (TGA) was used to study the thermal stability of these obtained products. Copyright ( $) 2020$ BCREC Group. All rights reserved
\end{abstract}

Keywords: Ethylene glycol dimethacrylate; Green catalyst; Maghnite- $\mathrm{H}^{+}$; Maghnite-Na+; Anionic polymerization

How to Cite: Haoue, S., Derdar, H., Belbachir, M., Harrane, A. (2020). Polymerization of Ethylene Glycol Dimethacrylate (EGDM), Using An Algerian Clay as Eco-catalyst (Maghnite- $\mathrm{H}^{+}$and Maghnite$\mathrm{Na}^{+}$). Bulletin of Chemical Reaction Engineering \& Catalysis, 15(1), 221-230 (doi:10.9767/bcrec.15.1.6297.221-230)

Permalink/DOI: https://doi.org/10.9767/bcrec.15.1.6297.221-230

\section{Introduction}

Since the discovery of the living anionic polymerization of styrene by Szwarc in 1956 [1], anionic polymerization of monomers such as styrene, 1,3-butadiene, isoprene, 2-vinylpyridine (2VP), and alkyl methacrylate monomers, is still the gold standard mechanism by which to obtain polymers with predictable, well-defined

* Corresponding Author.

Email: hodhaifa-27@outlook.fr (S. Haoue); structures [2]. Even though anionic polymerization is an excellent tool for the synthesis of welldefined polymers, it is limited in the range of monomers that are compatible to this polymerization technique. As a result, research is continuing to expand the library of monomers and polymerization conditions available in order to anionic produce next-generation materials that contain molecular heterogeneity and functional groups based on heteroatoms [3-7].

Producing polymers based on renewable monomers has been the subject of several cur- 
rent research groups around the world. Among different types of polymers explored, polymers based on renewable resources have been studied most extensively [8,9]. Polyethylene glycol (PEG) is a non toxic polymer with many applications in the industrial, medical and biological field. The first study and characterization of PEG was in 1860 by Laurenço [10]. PEG is the premise of various laxative, is also used as excipients in pharmaceutical products and toothpastes as a dispersant [11]. When joined to different protein prescriptions, PEG, also permits a slowed clearance of the carried protein in the blood, as well, it is used in many commercial products [12].

Various polyethylene glycol (PEG) macromonomers have been reported in the scientific literature for many years. These PEG macromonomers were prepared from block copolymers between PEG and biodegradable polyesters $[13,14]$ or by acrylation and methacrylation of PEG [15-18]. One of the main advantages of using PEG macromonomers is the preparation of biomaterials hydrogel. Over the past years, PEGDM was synthesized by reacting PEG with methacryloyl chloride and triethylamine in solution using Dichloromethane as a solvent, at room temperature overnight [19] and for $24 \mathrm{~h}$ [20], with another methods extending reaction time to 4 days [21] before filtration and precipitation in diethyl ether. However, all these approach are time-consuming and are not environmentally friendly, as they involve the use of relatively large amounts of toxic reagents and solvents.

The absence of termination and chain transfer reactions enables a high degree of control over the major variables affecting polymer properties, such as molecular weight, dispersity, chain-end and in-chain functionality, copolymer composition, molecular architecture, and block copolymer morphology. However, the synthesis of such well defined polymers requires extra care in the procedure and a suitable combination of monomer, solvent and initiator [22].

Heterogeneous catalysts based on clays have received considerable attention in different chemical processes due to their environmental compatibility, low cost, selectivity, thermal stability and recyclability [23,24]. They are one of the most widely studied solid acid catalysts for many organic transformations [25], such as: alkylation [26,27], condensation [28], dimerization [29], isomerisation [30,31], ether formation [32], transesterification reactions [33], and particularly in esterification reactions [34].

The novelty of this work is to study the synthesis of ethylene glycol dimethacrylate using a green and recyclable catalyst (Maghnite- $\mathrm{H}^{+}$), and to study its polymerization initiated directly by Algerian montmorillonite clay (Maghnite$\mathrm{Na}^{+}$. This new eco-catalyst has been used successfully to prepare and study several kinds of polymers [35-37]. First, we have synthesized the monomer ethylene glycol dimethacrylate (EGDM) by the condensation of ethylene glycol with methacrylic anhydride in bulk; and subsequently the polymerization of the obtained monomer was carried out under suitable and mild conditions. The advantage of the polymerisation of EGDM with Maghnite- $\mathrm{Na}^{+}$is the very short time of the reaction compared with classic methods.

\section{Materials and Method}

\subsection{Materials}

Ethylene glycol, methacrylic anhydride, methanol $\left(\mathrm{CH}_{3} \mathrm{OH}, 99.9 \%\right)$ and Dichloromethane $\left(\mathrm{CH}_{2} \mathrm{Cl}_{2}, 99.8 \%\right)$ are supplied by Sigma Aldrich and used as received. The raw montmorillonite clay was obtained from ENOF Maghnia (Algerian manufacture specialized in the production of non-ferric products and useful substances).

\subsection{Activation of Maghnite- $\mathrm{H}^{+}$}

Maghnite- $\mathrm{H}^{+}$was prepared according to the process reported in our previous study [38]. Maghnite- $\mathrm{H}^{+}$was activated with a sulfuric acid solution to give a Maghnite exchanged with protons, called Mag-H+. In an erlenmeyer flask, crushed raw Maghnite (20 g) was dispersed in a volume of distilled water $(120 \mathrm{~mL})$. The mixture was stirred $2 \mathrm{~h}$ at room temperature. Then, a solution of sulfuric acid $(0.25 \mathrm{M})$ was added. The solution thus obtained was maintained for two days under stirring. The mineral was filtered off and washed several times with distilled water up to $\mathrm{pH}$ 7. After filtration, Maghnite- $\mathrm{H}^{+}$is dried in an oven for 24

Table 1. Chemical composition of the "Maghnite" (Compositions wt\%)

\begin{tabular}{lccccccccc}
\hline Sample & $\mathrm{SiO}_{2}$ & $\mathrm{Al}_{2} \mathrm{O}_{3}$ & $\mathrm{Fe}_{2} \mathrm{O}_{3}$ & $\mathrm{CaO}$ & $\mathrm{MgO}$ & $\mathrm{Na}_{2} \mathrm{O}$ & $\mathrm{K}_{2} \mathrm{O}$ & $\mathrm{TiO}_{2}$ & $\mathrm{SO}_{3}$ \\
\hline Raw-Mag(\%) & 69.39 & 14.67 & 1.16 & 0.30 & 1.07 & 0.50 & 0.79 & 0.16 & 0.91 \\
Mag-H+H & 71.70 & 14.03 & 0.71 & 0.28 & 0.80 & 0.21 & 0.77 & 0.15 & 0.34 \\
\hline
\end{tabular}


$\mathrm{h}$, at $105{ }^{\circ} \mathrm{C}$ and was then crushed. Its structure was established by FT-IR and XRD. The composition of raw and treated Maghnite is given in Table 1 and the results show that the acid treatment leads to a decrease in $\mathrm{Al}_{2} \mathrm{O}_{3}$ concentration and silica enrichment in the material. The results also show a decrease in impurity levels such as iron oxide and calcite [39].

\subsection{Preparation of Maghnite- $\mathrm{Na}^{+}$}

Maghnite- $\mathrm{Na}^{+}$was prepared according to the protocol described by Belbachir et al. [40]. The raw Maghnite supplied by Bental Spa, was crushed and finely sieved, the activation of Maghnite by sodium was carried out using $1 \mathrm{~L}$ of $\mathrm{NaCl}$ solution (1 M) and $20 \mathrm{~g}$ of raw Maghnite ( $2 \%$ by weight), the latter was mixed for $24 \mathrm{~h}$ at room temperature, finally the Maghnite was washed several times with distilled water. The structure of Maghnite- $\mathrm{Na}^{+}$was confirmed by FT-IR and XRD analysis.

\subsection{Synthesis of Ethylene Glycol Dimethacry- late EGDM}

The synthesis of EGDM was carried out in bulk. In a flask containing 1 mole of ethylene glycol, we added an amount of $10 \mathrm{wt} \%$ of Maghnite- $\mathrm{H}^{+}$which is previously dried for 30 minutes in the oven at $105{ }^{\circ} \mathrm{C}$. The mixture was stirred for $1 \mathrm{~h}$ at room temperature $(25$ ${ }^{\circ} \mathrm{C}$ ), and then we added 2 mole of methacrylic anhydride with stirring for $3 \mathrm{~h}$. The solution was then filtered after adding $10 \mathrm{ml}$ of dichloromethane $\left(\mathrm{CH}_{2} \mathrm{Cl}_{2}\right)$ to recover Maghnite- $\mathrm{H}^{+}$. The catalyst was removed from the mixture by simple filtration. The filtrate was purified by ex-

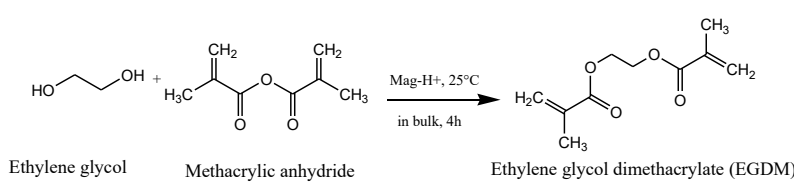

Scheme 1. Synthesis of EGDM monomer using Maghnite- $\mathrm{H}^{+}$.
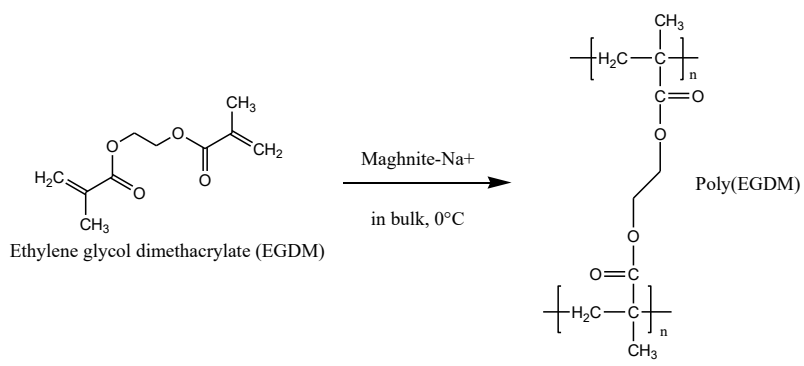

Scheme 2. Reaction of anionic polymerization of EGDM with Maghnite-Na+. traction $\mathrm{CH}_{2} \mathrm{Cl}_{2} / \mathrm{H}_{2} \mathrm{O}$ and dried under vacuum over night.

\subsection{Polymerization of Ethylene Glycol Di- methacrylate EGDM with Maghnite- $\mathrm{Na}^{+}$}

The polymerization of EGDM was carried out in a heterogeneous system. In an erlenmeyer flask, $1 \mathrm{~g}$ of EGDM and $10 \mathrm{wt} \%$ of Maghnite$\mathrm{Na}^{+}$were placed. The mixtures were stirred with a magnetic stirrer at $0{ }^{\circ} \mathrm{C}$ (using an ice bath). After $5 \mathrm{~h}$, the product was dissolved in $10 \mathrm{~mL}$ of dichloromethane. The catalyst was removed from the product by filtration. The resulting polymer was extracted with dichloromethane, precipitated in $100 \mathrm{~mL}$ of cold methanol. The precipitated polymer was then filtrated and dried in vacuum and weighed.

\subsection{Characterization}

The X-Ray powder diffraction profiles for pressed powder samples were recorded on a D8 Discover Bruker diffractometer using $\mathrm{Cu}-\mathrm{K} \alpha$ radiation $(\lambda=1.5418 \AA)$. FT-IR absorption spectra were recorded on an Alpha Bruker FTIR spectrometer. NMR is a very powerful analytical method for the elucidation of chemical structures. ${ }^{1} \mathrm{H}-\mathrm{NMR}$ and ${ }^{13} \mathrm{C}-\mathrm{NMR}$ spectra are recorded on a Bruker-Avance $400 \mathrm{MHZ}$ apparatus in deuterated chloroform. Polymer thermal stability was assessed using thermogravimetric analysis (TGA) using Perkin Elmer STA 6000 under nitrogen gas in the temperature range $30-700{ }^{\circ} \mathrm{C}$ with a heating rate of 20 ${ }^{\circ} \mathrm{C} / \mathrm{min}$ and the sample weighed about $6 \mathrm{mg}$. UV-Vis diffuse reflectance spectra were recorded using a SPECORD 210 Analytic Jena spectrometer.

\section{Results and Discussion}

\subsection{Characterization of Maghnite $\left(\mathrm{H}^{+}\right.$and $\left.\mathrm{Na}^{+}\right)$}

X-Ray diffractograms of Raw-Maghnite, Maghnite- $\mathrm{H}^{+}$and Maghnite- $\mathrm{Na}^{+}$are shown in

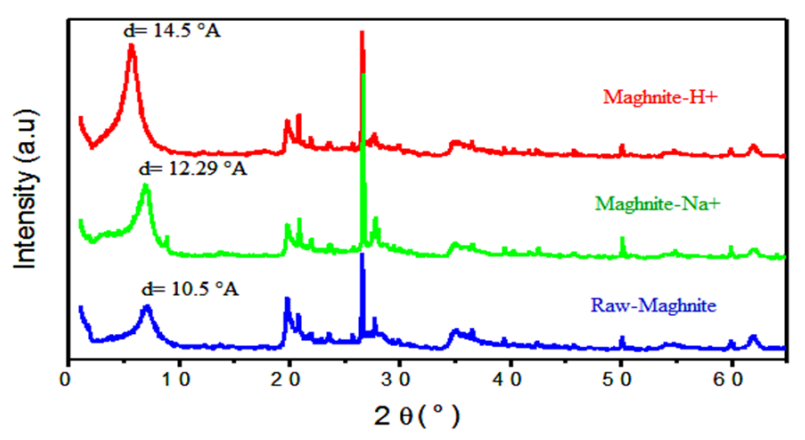

Figure 1. X-Ray diffractograms of RawMaghnite, Maghnite- $\mathrm{H}^{+}$and Maghnite- $\mathrm{Na}^{+}$. 
Figure 1. The calculated basal spacing (do01) from XRD patterns, applying Bragg's equation $(2 . d \cdot \sin \theta=n . \lambda)$ is $10.5 \AA$ for Raw-Maghnite and $14.5 \AA$ for Maghnite- $\mathrm{H}^{+}$. This increase in basal spacing is explained by the substitution of single water between the sheet of Raw-Maghnite by two interlamellar water layer in Maghnite$\mathrm{H}^{+}$. The XRD pattern of Maghnite- $\mathrm{Na}^{+}$shows that the calculated basal spacing is $12.29 \AA$. The obtained data show that Maghnite- $\mathrm{Na}^{+}$is a montmorillonite clay.

FT-IR spectra of Maghnite (Raw, $\mathrm{H}^{+}$and $\mathrm{Na}^{+}$) are shown in Figure 2; it is recorded in order to check the quality of the catalyst preparation. The hydrated structure of Maghnite- $\mathrm{H}^{+}$ results in characteristic vibrations of hydroxyl

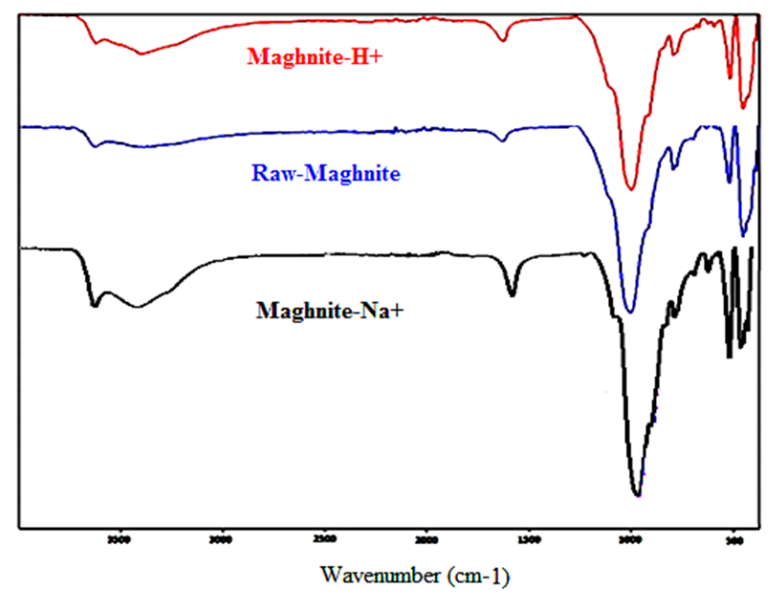

Figure 2. FT-IR spectrum of Raw-Maghnite, Maghnite- $\mathrm{H}^{+}$and Maghnite- $\mathrm{Na}^{+}$. groups around $3400 \mathrm{~cm}^{-1}$ and $3600 \mathrm{~cm}^{-1}$. Various Si-O vibrations mode at $1007 \mathrm{~cm}^{-1}, 756 \mathrm{~cm}$. 1, $518 \mathrm{~cm}^{-1}$, and $449 \mathrm{~cm}^{-1}$ can be attributed to the montmorillonite clay structure. All these expected absorption bands confirm that the structure of the compound is thus in good agreement with vibration values obtained from the literature [41]. FT-IR spectrum of Maghnite- $\mathrm{Na}^{+}$shows characteristics bands of montmorillonite clay and the results are comparable to other types of montmorillonite clay. The figure shows the following bands: the bands between 3388-3625 $\mathrm{cm}^{-1}$ are assigned to $\mathrm{Al}-\mathrm{AlOH}$ coupled by $\mathrm{Al}-\mathrm{MgOH}$ stretching vibrations. The bands between 1113 and $980 \mathrm{~cm}^{-1}$ are attributed to $\mathrm{Si}-\mathrm{O}$ out of plane and $\mathrm{Si}-\mathrm{O}-\mathrm{Si}$ ( 2 bands) in plane stretching. The deformation bands at $914 \mathrm{~cm}^{-1}, 792 \mathrm{~cm}^{-1}$ and $616 \mathrm{~cm}^{-1}$ are assigned to $\mathrm{Al}-\mathrm{AlOH}, \mathrm{AlFe}^{3+} \mathrm{OH}$ and $\mathrm{Al}-\mathrm{MgOH}$, respectively. The band at $515 \mathrm{~cm}^{-1}$ is attributed to either $\mathrm{Al}-\mathrm{OH}$ or Si-O bending or Al-O stretching vibration. The band at $449 \mathrm{~cm}^{-1}$ is assigned to $\mathrm{Si}-\mathrm{O}-\mathrm{Al}$ and $\mathrm{Si}-\mathrm{O}-\mathrm{Mg}$ coupled by $\mathrm{OH}$.

\subsection{Characterization of Ethylene Glycol Di- methacrylate (EGDM)}

3.2.1 NMR measurements $\left({ }^{1} \mathrm{H}-\mathrm{NMR}\right.$ and ${ }^{13} \mathrm{C}$ NMR)

${ }^{1} \mathrm{H}$ NMR spectra of the obtained monomer (EGDM) was recorded in $\mathrm{CDCl}_{3}$. The ${ }^{1} \mathrm{H}$ NMR spectrum allowed us to confirm the structure of the obtained product. The methacrylate end

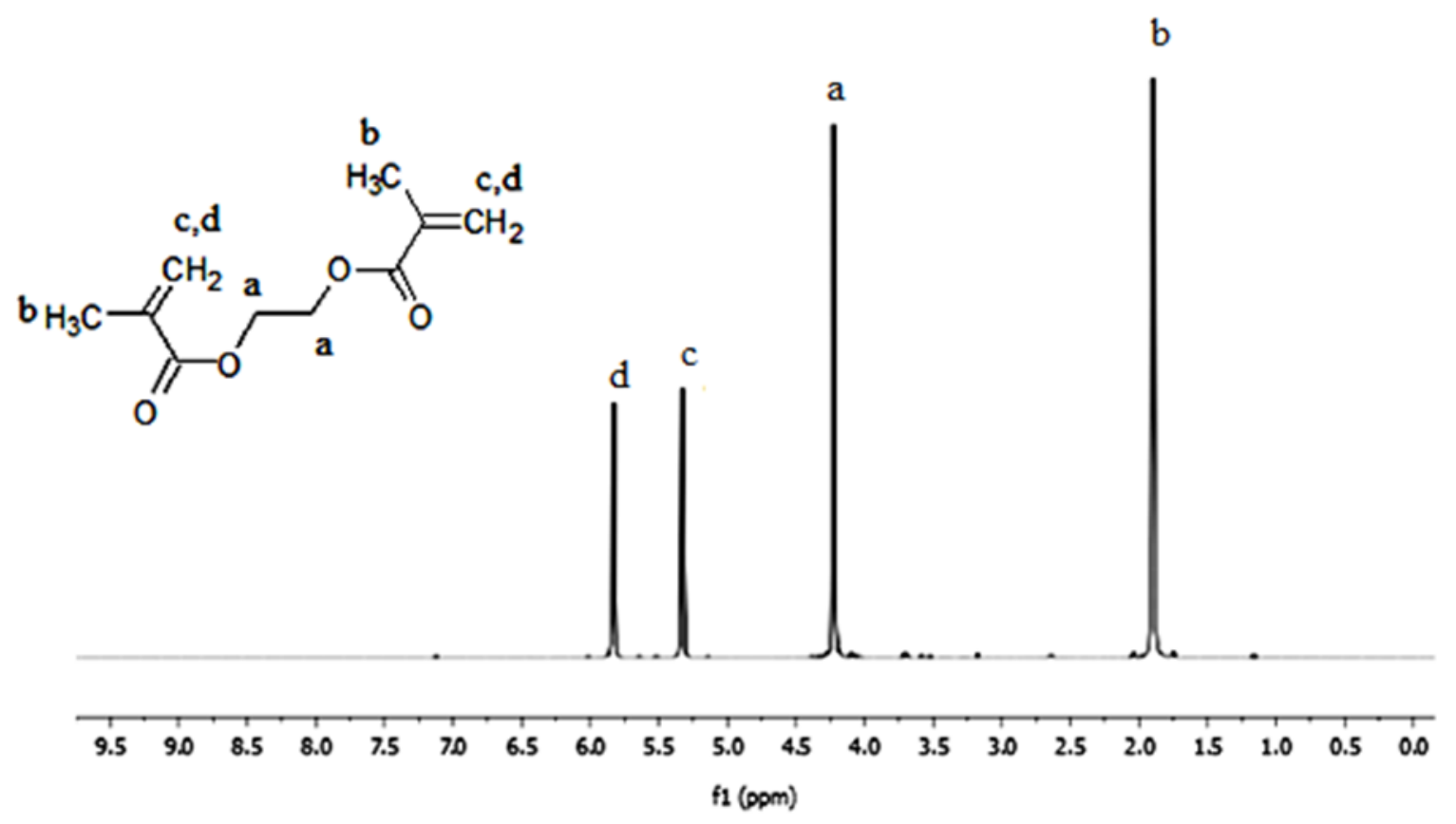

Figure 3. ${ }^{1} \mathrm{HNMR}$ spectrum of the obtained monomer (EGDM). 
groups were clearly visible in the ${ }^{1} \mathrm{H}-\mathrm{NMR}$ spectrum of monomer product, as shown in Figure 3. The protons of $=\mathrm{CH}_{2}$ end group assigned a signal at 5.4 and $5.9 \mathrm{ppm}$. The signal at $4.2 \mathrm{ppm}$ is attributed to the ethylene glycol protons and the signal observed at $1.9 \mathrm{ppm}$ is attributed to the methyl protons $\left(\mathrm{CH}_{3}\right)$ of methacrylic anhydride.

The ${ }^{13} \mathrm{C}-\mathrm{NMR}$ spectrum of EGDM is shown in Figure 4, the signal at $62 \mathrm{ppm}$ is attributed to the ethylene glycol carbons, and $\mathrm{C}=\mathrm{O}$ assigned a signal at $166.4 \mathrm{ppm} . \mathrm{CH}_{3}$ of methacrylic anhydride assigned a signal at 17.9 ppm. The vinylic carbons of methacrylic anhydride assigned a signal at 125.8 and $135.8 \mathrm{ppm}$, which clearly shows that the synthesis of EGDM monomer is successful with Maghnite$\mathrm{H}^{+}$.

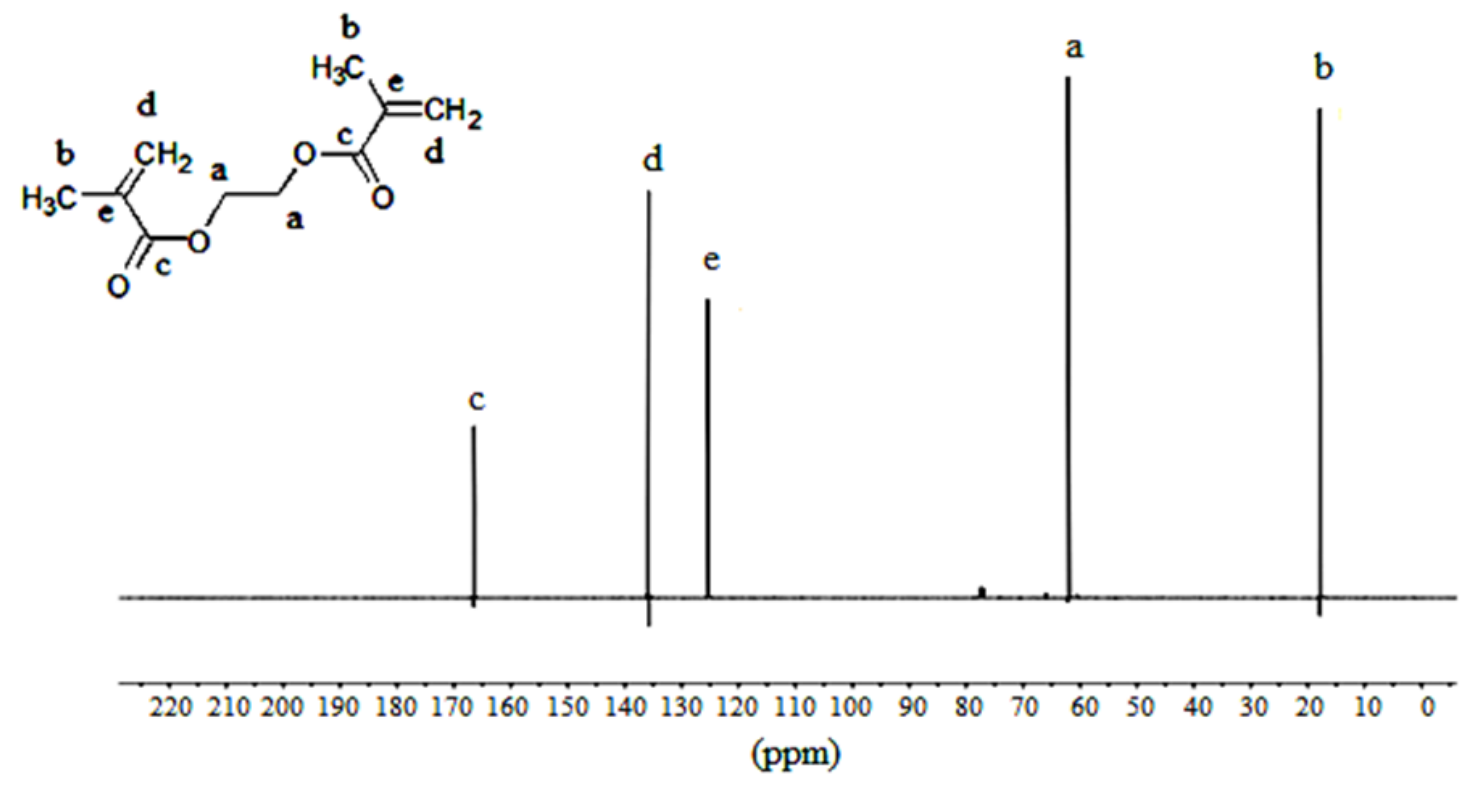

Figure 4. ${ }^{13} \mathrm{CNMR}$ spectrum of the obtained monomer (EGDM).

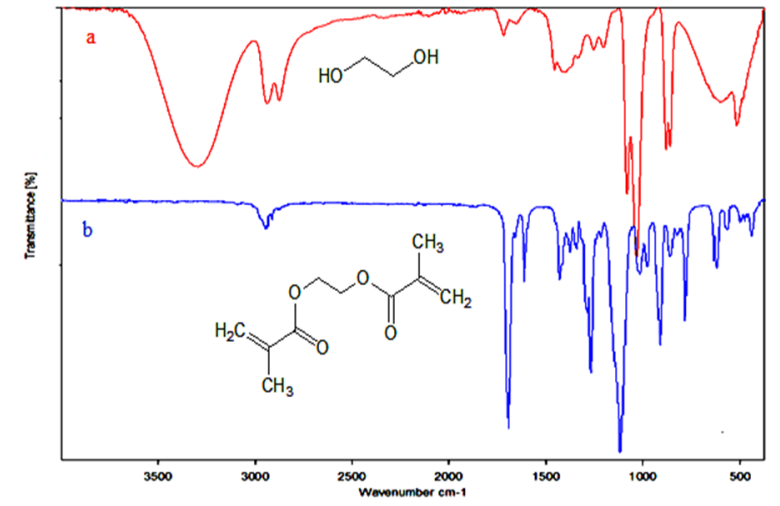

Figure 5. FTIR spectrums of ethylene glycol (a) and EGDM (b).

\subsubsection{Infrared Spectroscopy (FT-IR)}

FT-IR spectrums of EGDM have been shown, in Figure 5. The FT-IR spectrum of EGDM (Figure 5a) shows intense band at 1716 $\mathrm{cm}^{-1}$ correspond to the valence vibration of the $\mathrm{C}=\mathrm{O}$ of ester group, Methacrylate group being linked to the polymer chain end by an ester function. A less intense band at $1637 \mathrm{~cm}^{-1}$ corresponds to the valence vibration of the $\mathrm{C}=\mathrm{C}$ bond, compare to the spectrum of Ethylene glycol which those bands are nonexistent. The band at $2959 \mathrm{~cm}^{-1}$ corresponds to the $\mathrm{C}-\mathrm{H}$ of the monomer. It should be noted that the characteristic band corresponding to the band of $\mathrm{OH}$ groups at $3292 \mathrm{~cm}^{-1}$ in the spectra of EG (Figure 5a) have disappeared in the spectra of EGDM (Figure 5b). This would confirm that the synthesis of EGDM monomer is successful with Maghnite- $\mathrm{H}^{+}$.

\section{(ppm)}

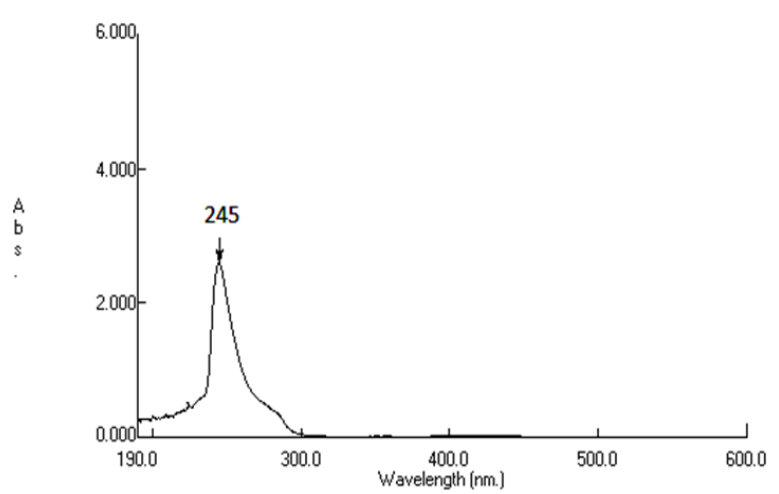

Figure 6. UV-Vis spectrum of the obtained monomer (EGDM). 


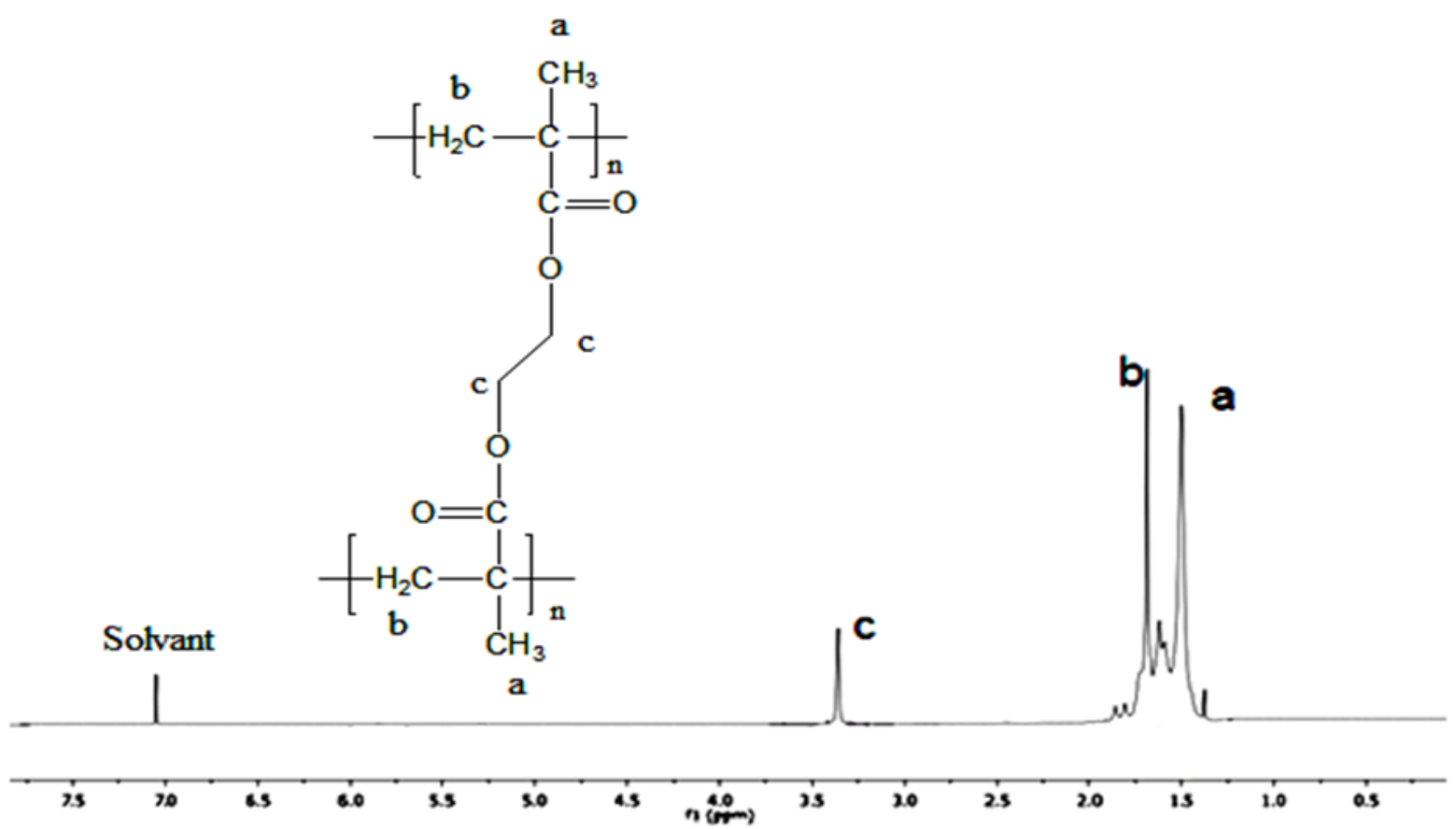

Figure 7. ${ }^{1} \mathrm{H}$ NMR spectrum of the obtained polymer (PEGDM).

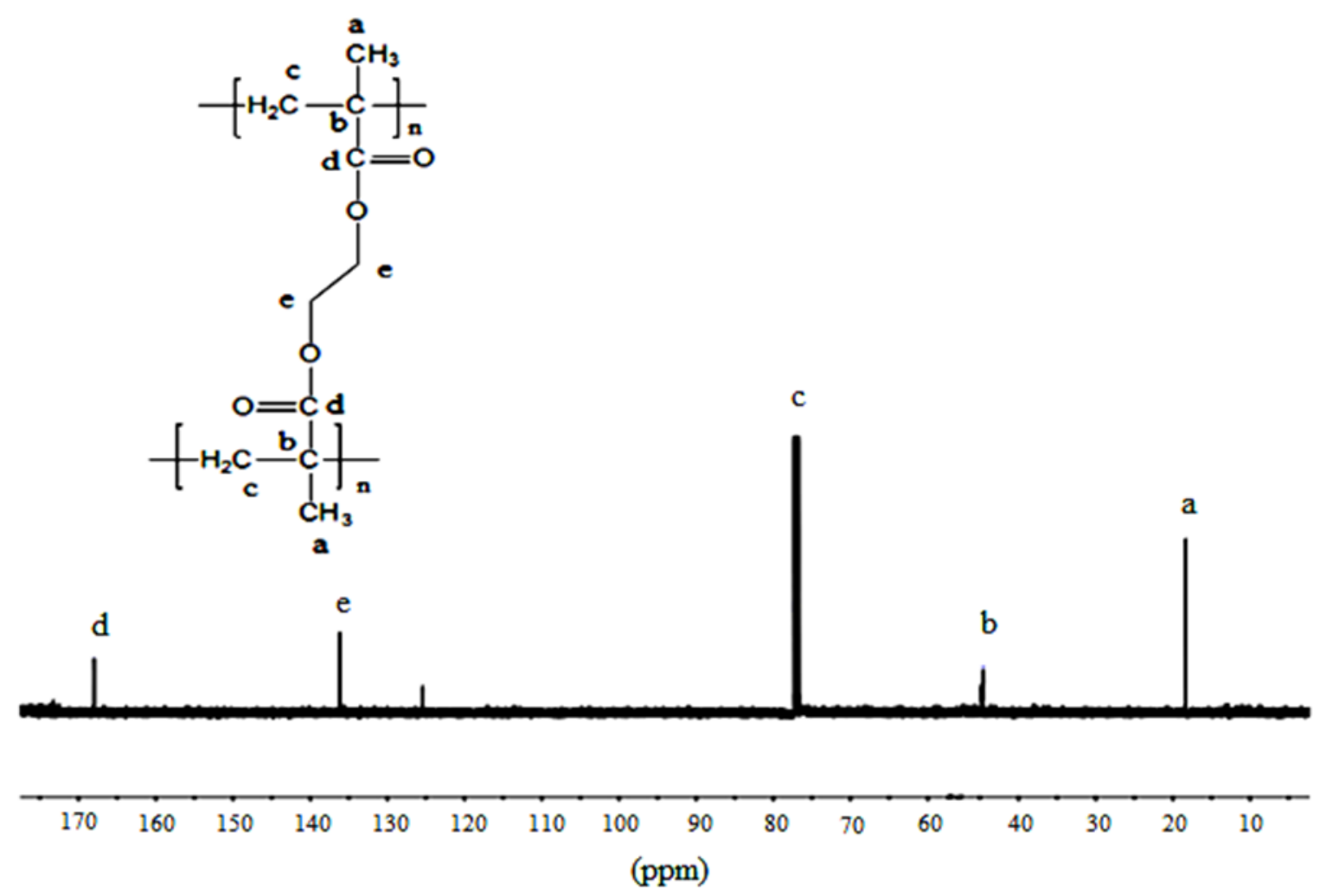

Figure 8. ${ }^{13} \mathrm{CNMR}$ spectrum of the obtained Polymer (PEGDM). 


\subsubsection{UV-Visible analysis (UV-Vis)}

UV analysis allows assaying the unsaturated end group. The dichloromethane was taken as a solvent, and $0.1 \mathrm{~g}$ of EGDM was diluted in $50 \mathrm{~mL}$ of dichloromethane and then its absorbance was measured. The double bond was observed at $\lambda=245 \mathrm{~nm}$ (Figure 6), UV-Vis analysis confirm the FT-IR and NMR analyses.

\subsection{Characterization of the Obtained Polymer (PEGDM)}

3.3.1 NMR measurements $\left({ }^{1} \mathrm{H}-\mathrm{NMR}\right.$ and ${ }^{13} \mathrm{C}$ NMR)

${ }^{1} \mathrm{H}-\mathrm{NMR}$ spectra of PEGDM was recorded in $\mathrm{CDCl}_{3}$. The ${ }^{1} \mathrm{H}-\mathrm{NMR}$ spectrum allowed us to confirm the structure of the obtained polymer, as shown in Figure 7. The protons of $-\mathrm{CH}_{2}$ assigned a signal at $1.7 \mathrm{ppm}$. The signal at 3.3 ppm is attributed to the ethylene glycol protons and the signal observed at $1.5 \mathrm{ppm}$ is attributed to the methyl protons $\left(\mathrm{CH}_{3}\right)$. In addition, the ${ }^{1} \mathrm{H}$-NMR spectrum of the obtained polymer shows that the peaks $\mathrm{c}$ and $\mathrm{d}$ at 5.4 and 5.9 $\mathrm{ppm}$ corresponding to the protons of the double bond $\left(=\mathrm{CH}_{2}\right)$ in EGDM were disappeared, this is confirm the polymerization of EGDM with Maghnite- $\mathrm{Na}^{+}$.

The ${ }^{13} \mathrm{C}$-NMR spectrum of PEGDM is shown in Figure 8, the signal at $134 \mathrm{ppm}$ is attributed to the ethylene glycol carbons, and $\mathrm{C}=\mathrm{O}$ function assigned a signal at $168 \mathrm{ppm} . \mathrm{CH}_{3}$ assigned a signal at $17.7 \mathrm{ppm}$. The asymmetric carbon of polymer assigned a signal at $48 \mathrm{ppm}$, the signal at $76 \mathrm{ppm}$ is attributed to $-\mathrm{CH}_{2}$ which clearly shows that the polymerization of EGDM is successful with Maghnite- $\mathrm{Na}^{+}$.

\subsubsection{FT-IR measurements}

FT-IR spectrum of PEGDM is shown in Figure 9. The FT-IR spectrum of PEGDM shows

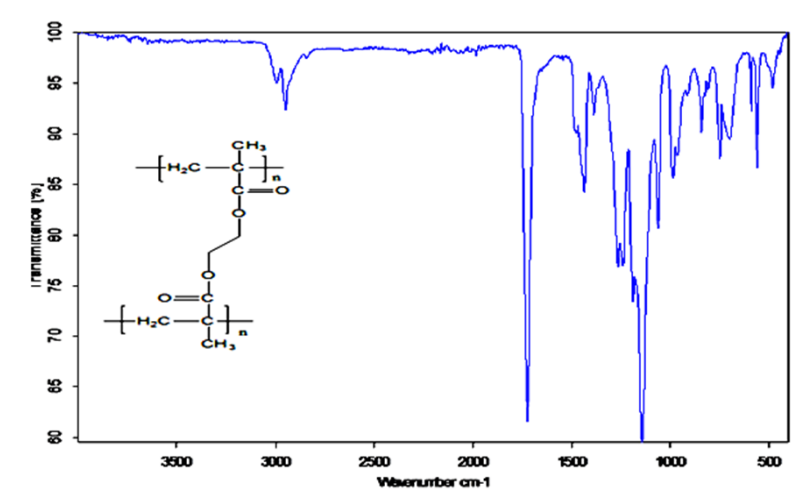

Figure 9. FTIR spectrum of PEGDM. intense band at $1716 \mathrm{~cm}^{-1}$ correspond to the valence vibration of the $\mathrm{C}=\mathrm{O}$ of ester group, this is confirm that the methacrylate group being linked to the end of polymer chain by an ester function, compare to the spectrum of PEG (Figure 5a) which those bands are nonexistent. In addition, Figure 9 shows clearly that the band corresponds to the valence vibration of the double bond $\mathrm{C}=\mathrm{C}$ at $1637 \mathrm{~cm}^{-1}$, is disappeared. The band at $2959 \mathrm{~cm}^{-1}$ corresponds to the $\mathrm{C}-\mathrm{H}$ of the polymer. This would confirm the polymerization of EGDM with Maghnite- $\mathrm{Na}^{+}$.

\subsubsection{Thermogravimetric Analysis (TGA)}

Thermal stability of the obtained monomer (EGDM) and the obtained polymer (PEGDM) are shown in Figure 10. The figure shows that the end capping with methacrylic anhydride is effective since degradation occurred at higher temperatures. This result confirms the previous ${ }^{1} \mathrm{H}-\mathrm{NMR}$ analysis. It can be found that at the temperature of $348{ }^{\circ} \mathrm{C}$ the weight loss amounted to $93 \%$, which can be reasonably attributed to the weight loss of the polymer and to the decomposition of PEGDM chains. The same results was obtained by Chu et al. [42].

3.4 Kinetic Study of the Synthesis of Polyethylene Glycol Dimethacrylate (PEGDM)

The objective of this part is to study the effect of various parameters including the quantity of the catalyst and the reaction time, on the yield of the obtained polymer in order to find the optimum conditions for the reaction. The yield was calculated by following equation:

$$
\text { yield }(\%)=\frac{M_{0}}{M_{1}} \times 100
$$

where $M_{0}$ is weight of the obtained macromonomer (PEGDM) and $M_{1}$ is weight of the initial monomer (EGDM).

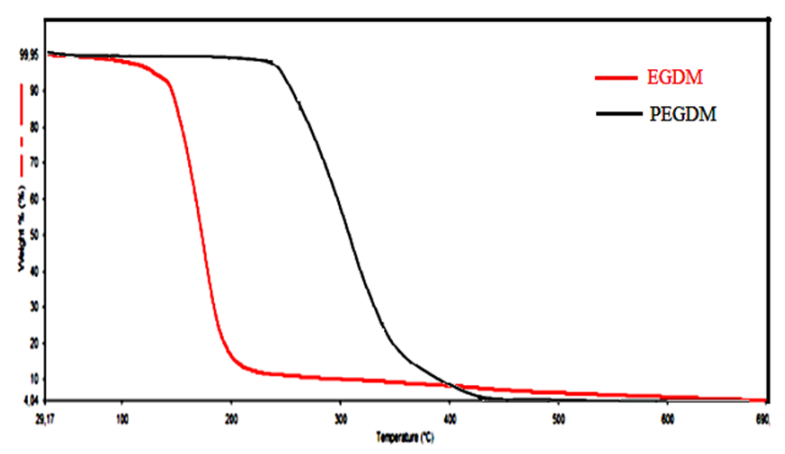

Figure 10. TGA curves of the obtained products. 


\subsubsection{Effect of Maghnite- $\mathrm{Na}^{+}$amount on the} yield of PEGDM

Figure 11 shows the effect of the amount of the catalyst on the yield of the obtained macromonomers (PEGDM). The synthesis was carried out at $0{ }^{\circ} \mathrm{C}$ for $5 \mathrm{~h}$ using various amounts of Maghnite- $\mathrm{Na}^{+}$(2, 5, 7, 10, and $\left.12 \mathrm{wt} \%\right)$. Figure 11 shows that the yield of macromonomers increased with the amount of Maghnite$\mathrm{Na}^{+}$. The output increases according to the quantity of Maghnite- $\mathrm{Na}^{+}$up to the optimal point, which corresponds to $10 \%$. This behavior is explained by the increase of active sites available in Maghnite- $\mathrm{Na}^{+}$responsible for the initiation and acceleration of the reaction until the saturation of these sites. Similar results were obtained by Belbachir and coworkers [43].

\subsubsection{Effect of the time on the yield of PEGDM}

Figure 12 shows the yield of the macromonomers versus time for the synthesis of PEGDM using Maghnite- $\mathrm{Na}^{+}$as catalyst. As the Figure shows that at the end of $5 \mathrm{~h}$, reaction takes place quickly and reaching the best yields (98\%) in presence of $10 \mathrm{wt} \%$ of Maghnite- $\mathrm{Na}^{+}$at $0{ }^{\circ} \mathrm{C}$. After this time, the reaction slows down gradually and the yield becomes almost constant. This behavior is explained by the nature of the reaction conducted in solution.

\section{Conclusion}

In the present work Maghnite has been modified using ion exchange process to obtain Maghnite- $\mathrm{H}^{+}$(proton exchanged process) and Maghnite- $\mathrm{Na}^{+}$(sodium exchanged process) as a non-toxic catalyst. FTIR and XRD analysis have proven that this clay belonged to the family of montmorillonite. The synthesis and the polymerization of EGDM were found to be initi-

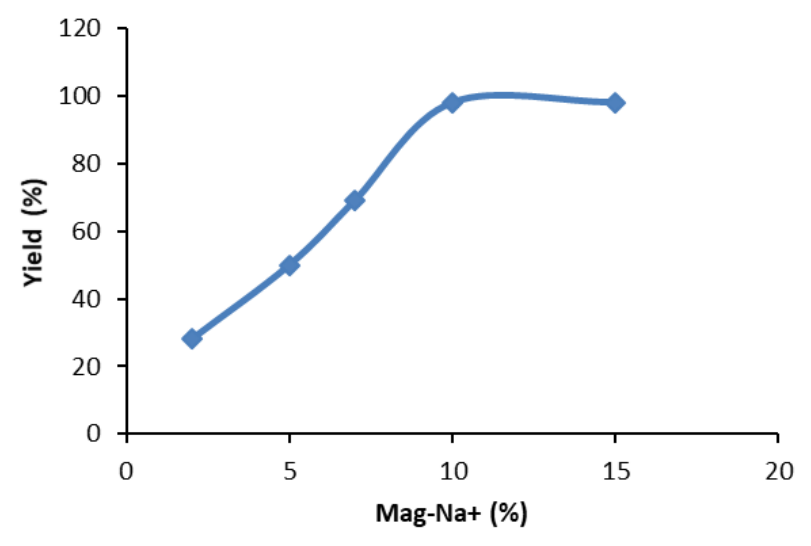

Figure 11. Effect of the amount of $\mathrm{Mag}-\mathrm{Na}^{+}$on the yield of PEGDM. ated by Maghnite- $\mathrm{H}^{+}$and Maghnite- $\mathrm{Na}^{+}$, respectively. The structure of the obtained monomer and polymer is confirmed by FT-IR, ${ }^{1} \mathrm{H}-\mathrm{NMR}$, and ${ }^{13} \mathrm{C}-\mathrm{NMR}$. The presence of unsaturated end group in the structure of monomer was confirmed by UV-Visible analysis. TGA analysis are used to study the thermal stability of the obtained polymer. Another interesting aspect is also that Maghnite can be easily separated from the polymer products and regenerated by heating to a temperature above $100{ }^{\circ} \mathrm{C}$.

\section{Acknowledgement}

We would like to thank the (DGRSDT) Direction Générale de la Recherche Scientifique et du Développement Technologique-Algeria, Pr G. Mitchell, and the CDRSP-IPLeiria (Centre for Rapid and Sustainable Product Development) for giving us access to their STA device. We also would like to thank Dr V.S. Mahendra, Dr A. Zaoui, and Dr M. Benachour for their help and advices through all the writing process.

\section{References}

[1] Szwarc, M. (1956). Living' Polymers. Nature, $178,1168-1169$.

[2] Hsieh, H.L., Quirk, R.P. (1996). Anionic Polymerization: Principles and Practical Applications, Marcel Dekker, New York.

[3] Wang, W., Lu, X., Bobade, S., Chen, J., Kang, N.-G., Zhang, Q., Mays, J. (2014). Synthesis and Characterization of Comb and Centipede Multigraft Copolymers PnBA-g-PS with High Molecular Weight Using Miniemulsion Polymerization. Macromolecules, 47, 7284-7295.

[4] Hirao, A., Shione, H., Ishizone, T., Nakahama, S. (1997). Anionic Polymerizations of 4-

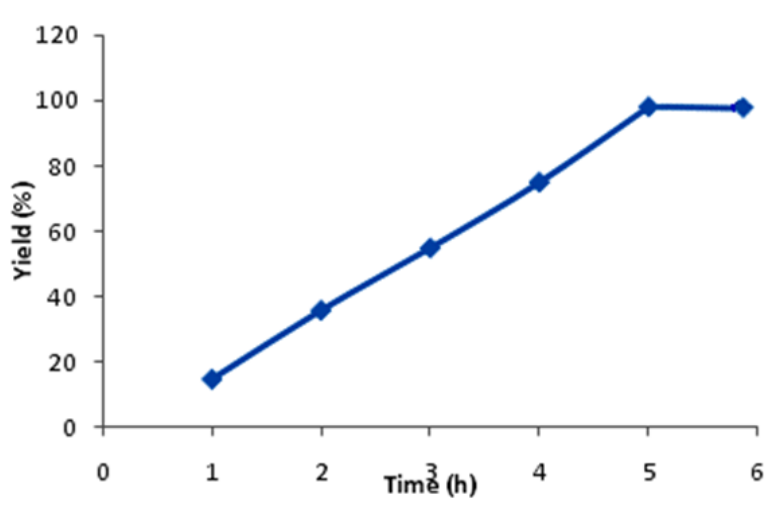

Figure 12. Effect of the reaction time on the yield of PEGDM. 
Vinylphenyl Methyl Sulfide, 4-Vinylbenzyl Methyl Sulfide, and 2-(4'-Vinylphenyl)ethyl Methyl Sulfide. Macromolecules, 30, 3728-3731.

[5] Ishizone, T., Kato, R., Ishino, Y., Hirao, A., Nakahama, S. (1991). Anionic Living Polymerizations of 2-(3-Vinylphenyl)-1,3dioxolane and Related Monomers. Macromolecules, 24, 1449-1454.

[6] Ishizone, T., Sugiyama, K., Hirao, A., Nakahama, S. (1993). Anionic Polymerizations of 2-, 3-, and 4-Cyanostyrene. Macromolecules, 26, 3009-3018.

[7] Hirao, A., Nakahama, S. (1998). Anionic Living Polymerization of Functionalized Monomers. Acta Polym., 49, 133-144.

[8] Fenouillot, F., Rousseau, A., Colomines, G., Saint-Loup, R., Pascault, J.P. (2010). Polymers from renewable $1,4: 3,6$ dianhydrohexitols (isosorbide, isomannide and isoidide): A review. Prog. Polym. Sci., 35, $578-622$.

[9] Lavilla, C., Martínez de Ilarduya, A., Alla, A., García-Martín, M.G., Galbis, G.A., Muñ ozGuerra, S. (2012). Bio-Based Aromatic Polyesters from a Novel Bicyclic Diol Derived from D-Mannitol. Macromolecules, 45, 8257-8266.

[10] Kricheldorf, H. (2013). Experiments before World war I. Polycondensation, 7-25.

[11] Emoto, K., Nagasaki, Y., Kataoka, K. (1999). Coating of Surfaces with Stabilized Reactive Micelles from Poly(ethylene glycol)-Poly(DLlactic acid) Block Copolymer. Langmuir, 15, 5212-5218.

[12] Kim, J.H., Emoto, K., Lijima, M., Nagasaki, Y., Aoyagi, T., Okano, T., Sakurai, Y., Kataoka, K. (1991). Core-stabilized polymeric micelle as potential drug carrier: increased solubilization of taxol. Polym. Adv. Technol., 10, 647-654.

[13] Kim, B.S., Hrkach, J.S., Langer, R. (2000). Biodegradable photo-crosslinked poly (etherester) networks for lubricious coatings. Biomaterials, 21, 259-265.

[14] Hern, D.L., Hubbell, J.A. (1998). Incorporation of adhesion peptides into nonadhesive hydrogels useful for tissue resurfacing. J. Biomed. Mater. Res., 39, 266-276.

[15] Lu, S., Anseth, K.S. (2000). Release Behavior of High Molecular Weight Solutes from Poly(ethylene glycol)-Based Degradable Networks. Macromolecules, 33, 2509-251.

[16] Scott, R.A., Peppas, N.A. (1999). Compositional effects on network structure of highly crosslinked copolymers of PEG-containing multiacrylates with acrylic acid. Macromolecules, 32, 6139-6148.
[17] Scott, R.A., Peppas, N.A. (1999). Kinetics of copolymerization of PEG-containing multiacrylates with acrylic acid. Macromolecules, $32,6149-6158$.

[18] Mann, B.K., Gobin, A.S., Tsai., A.T., Schmedlen., R.H., West, J.L. (2001). Smooth muscle cell growth in photopolymerized hydrogels with cell adhesive and proteolytically degradable domains: synthetic ECM analogs for tissue engineering. Biomaterials, 22, 30453051 .

[19] Benoit, DS., Anseth, KS. (2005). Heparin functionalized PEG gels that modulate protein adsorption for hMSC adhesion and differentiation. Acta Biomaterialia, 1, 461-470.

[20] Belbachir, M. (2001). U.S. Patent. 066969. 0101.

[21] Bentahar, M., Meghabar, R., Guemra, K., Belbachir, M. (2017). A Green Catalyst for Synthesis of Bis-Macromonomers of Poly (Styrene Oxide). Rev. Roum. Chim., 62, 839848.

[22] Hirao, A., Goseki, R., Ishizone, T. (2014). Advances in Living Anionic Polymerization: From Functional Monomers, Polymerization Systems, to Macromolecular Architectures. Macromolecules, 47, 1883-1905.

[23] Hensen, K., Mahaim, C., HiSlderich, W.F. (1997). Alkoxylation of limonene and alpha pinene over beta zeolite as heterogeneous catalyst. Applied Catalysis A: General, 149, 311329

[24] Zatta, L., Ramos, L.P., Wypych, F. (2013). Acid-activated montmorillonites as heterogeneous catalysts for the esterification of lauric acid acid with methanol. Appl. Clay Sci., 8081, 236-244.

[25] Reddy, C.R., Lyengar, P., Nagendrappa, G., Jai-Prakash, B.S. (2005). Esterification of dicarboxylic acids to diesters over $\mathrm{Mn}$ montmorillonite clay catalysts. Catal. Lett., 101, 87-91.

[26] Bouguerra, N.S., Trabelsi, M., Frikha, M.H. (2009). Esterification of fatty acids with short-chain alcohols over commercial acid clays in a semi-continuous reactor. Energ., 2, 1107-1117.

[27] Kaur, M., Sharma, S., Bedi, P.M.S. (2015). Sil-ica supported Brönsted acids as catalyst in organic transformations: A comprehensive re-view. Chin. J. Catal., 36, 520-549.

[28] Adriano, L.S.N., Tito, L.M.Z., Angélicab, R.S., Costa, C.E.F., Zamiana, J.R., Filhoa, G.N.R. (2011). Esterification of oleic acid over solid acid catalysts prepared from Amazon flint kaolin. Appl. Catal. B Environ., 101, 495-503. 
[29] Miranda, R., Valencia, V.O., Abel Maya, V.C., Nicolás, V.I., Vargas, R.Y.M., Morales, S.J.A., García, R.E., Salmón, M. (2013). Synthesis of cycloveratrylene macrocycles and benzyloligomers catalysed by bentonite under microwave/infrared and solvent-free conditions. Molecules, 18, 12820-12844.

[30] Fási, A., Pálinkó, I., Gömöryc, Á., Kiricsi, I. (2004). Ring opening, dimerisation and oligomerisation reactions of methyloxirane on solid acid and base catalysts. J. Molec. Catal. A Chem., 208, 307-311.

[31] Wiedemann, S.C.C., Stewart, J.A., Soulimani, F., Bergen-Brenkman, T., Langelaar, S., Wels, B., Peinder, P., Bruijnincx, P.C.A., Weckhuysen, B.M. (2014). Skeletal isomerisation of oleic acid over ferrierite in the presence and absence of triphenylphosphine: Pore mouth catalysis and related deactivation mechanisms. J. Catal., 316, 24-35.

[32] Perissinotto, M., Lenarda, M., Storaro, L., Ganzerla, R. (1997). Solid acid catalysts from clays: acid leached metakaolin as isopropanol dehydration and 1-butene isomerisation catalyst. J. Molec. Catal. A Chem., 121, 103-109.

[33] Lei, L., Plank, J. (2014). Synthesis and properties of a vinyl ether-based polycarboxylate superplasticizer for concrete possessing clay tolerance. Ind. Eng. Chem. Res., 53, 10481055.

[34] Sani, Y.M., Daud, W.M.A.W., Abdul Aziz, A.R. (2014). Activity of solid acid catalysts for biodiesel production: A critical review. Appl. Catal. A Gen., 470, 140-161.

[35] Ayat, M., Belbachir, M., Rahmouni, A. (2016). Selective synthesis, characterization, and kinetics studies of poly(a-Methyl styrene) induced by maghnite-Na+ clay (Algerian MMT). Bull. Chem. React. Eng. Catal., 11, 376-388.
[36] Bensaada, N., Ayat, M., Meghabar, R., Belbachir, M. (2015). The synthesis of polystyrene with a new chemical approach. Current Chemistry Letters, 4, 55-60.

[37] Rahmouni, A., Belbachir, M., Ayat, M. (2018). Structural inverstigation: anionic polymerisation of acrylamide under micowave irradiation using maghnite-Nap clay (Algerian MMT) as initiator. Bull. Chem. React. Eng. Catal., 13, 262-274.

[38] Derdar, H., Belbachir, M., Harrane, A. (2019). A Green Synthesis of Polylimonene Using Maghnite-H+, an Exchanged montmorillonite clay, as Eco-catalyst. Bull. Chem. React. Eng. Catal., 14, 69-78.

[39] Derdar, H., Belbachir, M., Hennaoui, F., MAkeb, M., Harrane, A. (2018). Green Copolymerization of Limonene with B-Pinene Catalyzed by an Eco-Catalyst Maghnite$\mathrm{H}^{+}$. Polym. Sci. B, 60, 555-562.

[40] Derkaoui, S., Belbachir, M., Haoue, S., Zeggai, F.Z., Rahmouni, A., Ayat, M. (2019). Homopolymerization of methacrylamide by anionic process under effect of Maghnite- $\mathrm{Na}^{+}$ (Algerian MMT). J. Organomet. Chem., 893, $52-60$.

[41] Cherifi, Z., Boukoussa, B., Zaoui, A., Belbachir, M., Maghabar, R. (2018). Structural, morphological and thermal properties of nanocomposites poly(GMA)/clay prepared by ultrasound and in-situ polymerization. Ultrason. Sonochem., 48, 188-198.

[42] Chu, C.H., Ho, N.M., Tong, T.T.C. (2015), Synthesis of Coagent Ethylene Glycol Dimethacrylate. Malays. J. Chem., 17, 26-31.

[43] Yahiaoui, A., Belbachir, M. (2006). Ring-opening polymerization of styrene oxide with Maghnite- $\mathrm{H}^{+}$as ecocatalyst. J. Appl. Polym. Sci., 100, 1681-1687. 